SUÁREZ-HERNÁNDEZ, AM; VÁZQUEZ-ANGULO, JC; GRIMALDO-JUÁREZ, O; CECEÑA-DURÁN, C; GONZÁLEZ-MENDOZA, D; BAZANTEGONZÁLEZ, I; MENDOZA-GÓMEZ, A. 2019. Production and quality of grafted watermelon in saline soil. Horticultura Brasileira 37: 215-220. DOI - http://dx.doi.org/10.1590/S0102-053620190213

\title{
Production and quality of grafted watermelon in saline soil
}

\author{
Ángel Manuel Suárez-Hernández ${ }^{1} \mathbb{D}$; Juan Carlos Vázquez-Angulo ${ }^{1} \mathbb{D}$; Onécimo Grimaldo-Juárez² ${ }^{\mathbb{D}}$; Carlos \\ Ceceña-Durán ${ }^{2} \mathbb{D}$; Daniel González-Mendoza ${ }^{2} \mathbb{D}$; Isidro Bazante-González ${ }^{1} \mathbb{D}$; Aurelia Mendoza-Gómez ${ }^{1} \mathbb{D}$
}

${ }^{1}$ Autonomous University of Baja California, Faculty of Engineering and Business San Quintin, Ensenada, Mexico; suarez.angel@uabc. edu.mx; jcva@uabc.edu.mx; isidro@uabc.edu.mx; aurelia.mendoza@uabc.edu.mx; ${ }^{2}$ Autonomous University of Baja California, Institute of Agricultural Sciences, Mexicali, Mexico; onecimo.grimaldo@uabc.edu.mx (correspondence author); carlos.cecena.duran@uabc.edu. mx; danielg@uabc.edu.mx

ABSTRACT

Salinity of soil in arid and semiarid regions is a problem that affects the production and quality of fruit. That's while we evaluated grafting on watermelon plants as an alternative to reduce the salinity effects. The experimental design was of randomized blocks, three treatments (cultivars Sangria, Summer Flavor 800 and Summer Flavor 840) with three repetitions. The cultivars were evaluated in grafted and ungrafted condition. The rootstock used for grafting was the interspecific hybrid Strong Tosa (C. maxima x C. moschata). In average terms for the three cultivars, grafting increased commercial production, weight, length and diameter of fruits in $160.5 \%, 36.5 \%$, $12.0 \%$ and $7.5 \%$, respectively. Sangria presented the best answer in production with $57.1 \mathrm{t} \mathrm{ha}^{-1}$, weight $5.8 \mathrm{~kg}$, length $35.0 \mathrm{~cm}$ and diameter $17.8 \mathrm{~cm}$ of fruits. Also, grafting favored in $6.3 \%$ the luminosity and reduced $6.4 \%$ Hue angle. Summer Flavor 840 showed the best result in luminosity with 48.3 and hue angle $26.4^{\circ}$. Firmness, ${ }^{\circ}$ Brix and lycopene content were not modified by grafting. Grafting represents an alternative for watermelon production in saline soils, improving yield and quality of the fruits.

Keywords: Citrullus lanatus, graft, salinity, pulp color, lycopene.

\section{RESUMO}

\section{Produção e qualidade de melancia enxertada, em solo salino}

A salinidade do solo em regiões áridas e semi-áridas afeta a produção e qualidade de frutos da melancieira. Objetivou-se com esse trabalho avaliar a condição enxertada da planta como alternativa para reduzir os efeitos da salinidade. Foi utilizado o delineamento em blocos casualizados com três repetições. As cultivares Sangria, Summer Flavor 800 e Summer Flavor 840 constituiram os tratamentos, como planta com e sem enxertia. $\mathrm{O}$ enxerto foi realizado sobre o híbrido interespecífico Strong Tosa (C. maxima x C. moschata). O enxerto favoreceu a produção comercial, peso, comprimento e diâmetro do fruto em $160,5 \%, 36,5 \%, 12,0 \%$ e 7,5\%, respectivamente, em termos médios das três cultivares. 'Sangria' apresentou a melhor resposta em produtividade com $57,1 \mathrm{t} \mathrm{ha}^{-1}$, peso $5,8 \mathrm{~kg}$, comprimento $35,0 \mathrm{~cm}$ e diâmetro $17,8 \mathrm{~cm}$ de fruto. $\mathrm{O}$ enxerto favoreceu em $6,3 \%$ o valor de luminosidade e redução de 6,4\% no ângulo hue. 'Summer Flavor 840' apresentou a melhor resposta em luminosidade com valor de 48,3 e ângulo hue de $26,4^{\circ}$. Firmeza, ${ }^{\circ}$ Brix e teor de licopeno não foram afetados pela enxertia. $\mathrm{O}$ enxerto das plantas constitui alternativa em solos salinos para melhorar a produção e qualidade dos frutos.

Palavras-chave: Citrullus lanatus, enxerto, salinidade, cor da polpa, licopeno.

\section{Received on June 15, 2018; accepted on February 25, 2019}

$\mathrm{T}$ he agricultural production systems decrease in yield by biotic and abiotic factors (Rivero et al., 2003). Among these factors is the salinity of the soil, constantly aggravated due to natural or anthropogenic origins. High concentration of salt affects growth and development of crops (Colla et al., 2010), causing premature senescence of plants. In arid and semiarid regions this phenomenon is promoted by agricultural activity, environmental conditions and shortage of good quality water (PulidoMadrigal, 2016). Lack of water makes impossible the transport of soluble salts to deeper layers, favoring the precipitation of salts on the arable surface of the soil (Acosta et al., 2011).

In agricultural zones where the temperature is between 31 and $47^{\circ} \mathrm{C}$ with minimal precipitation in high temperature months, the electrical conductivity of the soil tends to increase due to the movement of the soluble salt through evaporation and capillary ascent (Acosta et al., 2011). Studies about physicochemical properties of the soil, show that in these regions the problems of saline concentration increases in 24 and $16 \%$ on profiles of 30 and $60 \mathrm{~cm}$, respectively (Pulido-Madrigal, 2016). In 2004, salt levels superior to $8.0 \mathrm{dS} \mathrm{m} \mathrm{m}^{-1}$ on arid and semiarid regions in Mexico, were reported (SEFOA, 2011). Levels superior to $4.0 \mathrm{dS} \mathrm{m}^{-1}$ generate light to strong problems to the plant growth.

A strategy used to counteract the severe problems of salinity is leaching the soil of salt (Dong et al., 2018). This is an impossible practice in arid or semiarid zones, because it would require high volumes and continuous flow of water. Additionally, the water must be low in salt. The use of tolerant varieties (Furtana \& Tipirdamaz, 2010), polyamines (Duan et al., 2008) and plant growth-promoting bacteria (Sanjay et al., 2017) are other alternatives used to 
reduce the effects of salinity. But some of them depend on the environment conditions to ensure effectiveness.

The implementation of the graft technique showed an increase in salinity tolerance of watermelon crops, due to the characteristics of ionic regulations of the radicular system of the rootstock (Yetisir \& Uygur, 2010). Rootstocks as hybrid C. maxima x C. moschata, cultivar Strong Tosa, promoted the activity of antioxidant enzymes and exclusion of sodium of the cells in answer to saline stress (Goreta et al., 2008). Additional benefits of the graft are efficiency in the use of water and minerals (Rouphael et $a l ., 2008)$, expressed in higher vegetal growth and fruit production. The fruit quality also is benefited by the graft (Soteriou et al., 2014).

Watermelon is a moderately sensible plant to salinity, where, values 3.5 and $4.5 \mathrm{dSm}^{-1}$ reduce the production in 25 and $50 \%$, respectively (Ali et al., 2015). The forecast of success of watermelon crops in superior conditions of 8.0 $\mathrm{dS} \mathrm{m}^{-1}$ is not very promising for the farmers dedicated to this activity in arid and semiarid zones. For this reason in the present investigation we evaluated three watermelon hybrids in grafted and ungrafted conditions, to evaluate production and quality of watermelon in a saline soil with $11.9 \mathrm{dS} \mathrm{m}^{-1}$ electrical conductivity.

\section{MATERIAL AND METHODS}

The present study was conducted at experimental field institute of agricultural sciences of the Autonomous University of Baja California, from February 10 to July 1, 2012, in the Mexicali valley near Mexicali, Baja California, Mexico (32 $24^{\prime} 19^{\prime \prime} \mathrm{N}, 115^{\circ} 11^{\prime} 48^{\prime \prime} \mathrm{W}$, $14 \mathrm{~m}$ altitude). The climate of the region is very dry with $13.6^{\circ} \mathrm{C}$ and $31.7^{\circ} \mathrm{C}$ minimal and maximal annual temperature, respectively. Annual precipitation is $10 \mathrm{~mm}$. The highest temperatures are present from May to September with oscillations from 36 to $45^{\circ} \mathrm{C}$. The experiments were established under a clayey soil with $\mathrm{pH} 8.0$, electrical conductivity $11.9 \mathrm{dS}$ $\mathrm{m}^{-1}$, and RAS of 7.2, PSI 1.5 and water mantle level (1.5 to $2.0 \mathrm{~m}$ depth). The physicochemical properties of soil were chlorine 2127 ppm, sulfate 1921 ppm, sodium 990 ppm, calcium 957 ppm, nitrate $775 \mathrm{ppm}$, bicarbonate 419.75 ppm, magnesium $285 \mathrm{ppm}$, potassium $180 \mathrm{ppm}$, carbonate $6 \mathrm{ppm}$, and diacid phosphate $5.76 \mathrm{ppm}$.

The evaluated genetic material consisted of three hybrid watermelons, types Allsweet Sangria, Summer Flavor 800 and Summer Flavor 840, in normal (control) and grafted conditions. The puatechnical graft was used and the rootstock was the interspecific hybrid Strong Tosa (C. maxima $\mathrm{x} C$. moschata). Plantlets were transplanted at the stage of four leaves. Experimental design was of randomized blocks with three repetitions per treatment. Each experimental unit consisted of 32 plants with a frame plantation of $2.0 \times 0.8 \mathrm{~m}$ and useful plot of 20 plants.

Water and fertilizer supply was through drip irrigation system. The water presented CE $1.3 \mathrm{dS} \mathrm{m}^{-1}$ and $\mathrm{pH}$ 8.4. Water volume was estimated in accordance to crop evapotranspiration (Etc) using the equation $E t c=$ Eto $\mathrm{x}$ $\mathrm{Kc}$, considering weekly value readings of reference evapotranspiration (ETo) obtained of weather station located at 585 $m$ of the experimental unit $\left(32^{\circ} 24^{\prime} 39^{\prime \prime} \mathrm{N}\right.$, $\left.115^{\circ} 11^{\prime} 50^{\prime \prime} \mathrm{W}\right)$. During the crop cycle we used crop coefficient $(\mathrm{Kc})$ values 0.4 in initial phase, 0.8 in vegetative phase, 1.0 in flowering phase and 0.8 in fruit fattening phase. Fertilization per hectare was $129 \mathrm{~kg} \mathrm{~N}, 92 \mathrm{~kg} \mathrm{P}_{2} \mathrm{O}_{5}$ and $154 \mathrm{~kg} \mathrm{~K}_{2} 0$ complemented with 61.5 $\mathrm{kg} \mathrm{CaO}$ and $15 \mathrm{~kg} \mathrm{MgO}$. Harvest point was defined at stipule drying and tendril next to the peduncle of the fruit. We evaluated the commercial production $\left(\mathrm{t} \mathrm{ha}{ }^{-1}\right)$, fruit weight $\left(\mathrm{kg}\right.$ fruit $\left.{ }^{-1}\right)$, length and diameter $(\mathrm{cm})$ of fruit, color $(\mathrm{LCh})$ and firmness $(\mathrm{N})$ of the pulp, content of solid soluble ( ${ }^{\circ}$ Brix) and lycopene $\left(\mathrm{mg} \mathrm{kg}^{-1}\right)$. Color was determined with sphere spectrophotometer; the obtained values were registered as lightness $\left(\mathrm{L}^{*}\right)$, chroma $\left(\mathrm{C}^{*}\right)$ and hue angle $\left(\mathrm{h}^{\circ}\right) . \mathrm{L}^{*}$ value defines color clarity and it goes from 0 (black) to 100 (white). $C^{*}$ value indicates the color saturation, varying from 0 (gray) to 100 (pure hue). $h^{\circ}$ value indicates hue angle expressed in grades, from 0 to $360^{\circ}$.

Pulp firmness was quantified through digital force gauge, expressed in newton $(\mathrm{N})$. Total soluble solids content was determined with a refractometer, expressed in ${ }^{\circ} \mathrm{Brix}$. Lycopene concentration was defined by spectrophotometry through extract of tissue obtained with acetone (D'Souza et al., 1992). Absorbance was measured to $503 \mathrm{~nm}$ using a spectrophotometer. Concentration was calculated using the equation $\mathrm{C}\left(\mathrm{mg} \mathrm{kg}^{-1}\right)=(\mathrm{A} 503 / 172000)$ x $0.55 \mathrm{~V}$ x $537 \times(1 / \mathrm{W}) \times 106$, where, $\mathrm{V}=$ solvent volume $(\mathrm{mL}), \mathrm{W}=$ sample weigth $(\mathrm{mg})$ and $\mathrm{A} 503=$ absorbance to $503 \mathrm{~nm}$.

Obtained data were analyzed using orthogonal contrasts test with the Statistical Analysis System program version 9.0. Orthogonal contrasts were used to compare 1) Sangria vs Sangria/ Strong Tosa, 2) Summer Flavor 800 vs Summer Flavor 800/Strong Tosa, 3) Summer Flavor 840 vs Summer Flavor $840 /$ Strong Tosa and 4) ungrafted plants vs grafted plants. Least square means and standard errors were calculated at 0.05 probability levels.

\section{RESULTS AND DISCUSSION}

The commercial production of the grafted watermelon plants was higher $(\mathrm{P}<0.001)$ in comparison with nongrafted plants. These differences are due to increment of weight and dimension of fruits, where in grafted condition produced fruits presented higher weight $(\mathrm{P}<0.001)$, length $(\mathrm{P}<0.01)$ and diameter $(\mathrm{P}<0.01)$ (Table 1). The characteristics of the pulp like firmness, ${ }^{\circ}$ Brix and lycopene did not vary $(\mathrm{P}>0.05)$, except the color, where luminosity and tone varied (Table 2).

The cultivar with the highest commercial production with graft was Sangria with $57.1 \mathrm{t} \mathrm{ha}^{-1}, 278 \%$ superior to its normal condition (15.1 $\mathrm{t} \mathrm{ha}^{-1}$ ) (Figure 1A). Cultivars Summer Flavor 800 and Summer Flavor 840 had an increase of $123 \%$ and $118 \%$ with production of 53.9 and $44.3 \mathrm{t} \mathrm{ha}^{-1}$, respectively. The production of grafted plants was higher than the national average $27.5 \mathrm{t} \mathrm{ha}^{-1}$ (SEFOA, 2011), 
Table 1. Mean, standard error of the mean (SEM) and orthogonal contrast (C) of the production parameters in three watermelon cultivars under normal and grafted condition. Mexicali, UABC, 2012.

\begin{tabular}{|c|c|c|c|c|c|c|c|}
\hline \multirow[b]{2}{*}{ Variables } & \multicolumn{3}{|c|}{ Normal plant } & \multicolumn{3}{|c|}{ Grafted plant } & \multirow[b]{2}{*}{ SEM } \\
\hline & Sangría & $\begin{array}{c}\text { Summer } \\
\text { Flavor } 800\end{array}$ & $\begin{array}{c}\text { Summer } \\
\text { Flavor } 840\end{array}$ & Sangría & $\begin{array}{c}\text { Summer } \\
\text { Flavor } 800\end{array}$ & $\begin{array}{c}\text { Summer } \\
\text { Flavor } 840\end{array}$ & \\
\hline $\begin{array}{l}\text { Commercial } \\
\text { production }\left(\mathrm{t} \mathrm{ha}^{-1}\right)\end{array}$ & 15.1 & 24.2 & 20.3 & 57.1 & 53.9 & 44.3 & 5.8 \\
\hline Fruit weight (kg) & 4.1 & 4.6 & 4.8 & 5.8 & 5.6 & 6.0 & 0.2 \\
\hline Length $(\mathrm{cm})$ & 31.1 & 29.1 & 32.4 & 35.0 & 32.4 & 36.3 & 1.1 \\
\hline Diameter $(\mathrm{cm})$ & 16.0 & 18.0 & 17.8 & 17.8 & 19.8 & 18.1 & 0.5 \\
\hline
\end{tabular}

\begin{tabular}{lrccc} 
& \multicolumn{4}{c}{ Contrast P>F } \\
\cline { 2 - 5 } & C1 & C2 & C3 & C4 \\
\hline Commercial production $\left(\mathrm{t} \mathrm{ha}^{-1}\right)$ & $<0.001$ & 0.005 & 0.015 & $<0.001$ \\
Fruit weight $(\mathrm{kg})$ & $<0.001$ & 0.021 & 0.004 & $<0.001$ \\
Length $(\mathrm{cm})$ & 0.026 & 0.051 & 0.031 & 0.002 \\
Diameter $(\mathrm{cm})$ & 0.022 & 0.029 & 0.671 & 0.008 \\
\hline
\end{tabular}

${ }^{1}$ Orthogonal contrast: $\mathrm{C} 1=$ Sangría vs Sangría grafted condition; $\mathrm{C} 2=$ Summer Flavor 800 vs Summer Flavor 800 grafted condition; C3= Summer Flavor 840 vs Summer Flavor 840 grafted condition; $\mathrm{C} 4=$ normal plant vs grafted plant.

value that could reduce a $50 \%$ in saline condition superior to $4 \mathrm{dS} \mathrm{m}^{-1}$ in soil. Zong et al. (2011) reported a decrease of $51.5 \%$ in watermelon cv. Seed Melon- 1 when saline concentration in the water increases at $6.1 \mathrm{dS} \mathrm{m}^{-1}$.

The fruit size, generally, was promoted by the graft condition in weight, and diameter (Table 1). Fruit weight of the three grafted watermelon cultivars increased in comparison to normal condition (Figure 1B), showing an increase of $1.7 \mathrm{~kg}$ of cv Sangria producing 5.8-kg fruits, while Summer Flavor 840 and Summer Flavor 800 increased from 1.0 to $1.2 \mathrm{~kg}$. Fruits of the three cultivars increased in length from 3.3 to $3.8 \mathrm{~cm}$, which represented an increase of 10.5 to $11.7 \%$ (Figure 1C). In diameter, Sangria and Summer Flavor 800 presented a high increase of $2.0 \mathrm{~cm}$ in comparison to plants without graft, while Summer Flavor 840 did not show any difference when both plant conditions were compared (Figure 1D).

The increase in size of the fruit due to graft in saline condition soil, coincides with the investigation done by Colla et al (2006) who found an increase in the fruit size when irrigating plants with water with saline concentration higher than $4 \mathrm{dSm}^{-1}$. Tolerance to salinity of grafted plants could be attributed to mechanisms of the rootstock (Niu et al., 2017), as reduced absorption, translocation and exclusion of ions $\mathrm{Na}^{+}$ and $\mathrm{Cl}^{-}$(Goreta et al., 2008; Edelstein et al., 2011; Lei et al., 2014). Some studies of the rootstock Strong Tosa showed that it induces anatomical changes and promotes activity of some antioxidant enzymes in response to saline stress and effectiveness in the exclusion of $\mathrm{Na}^{+}$of the stem (Goreta et al., 2008). Other characteristics related to rootstocks are higher absorption of essential elements under saline stress as calcium, magnesium, potassium (Yetisir \& Uygur, 2010) and the improved metabolic activity of nitrogen (Yang et al., 2013). On the other hand, Colla et al. (2013) mention that the rootstock induced a higher content of chlorophyll, photosynthetic activity and a better nutritional status which favors a higher increase and production of the plant, even under saline stress.

The quality of the fruit under saline floor conditions was not modified in a meaningful way in most cases by graft effect (Table 2). Generally, the behavior of the three cultivars, only established differences in color of the pulp, lightness $(\mathrm{P}<0.01)$ and hue angle $(\mathrm{P}<0.001)$. Pulp color of fruits from grafted plants increased lightness from 44.0 (dark color) to 46.9 (light color) compared to plants without graft. Color (hue angle) of fruits was 28.77 when obtained from ungrafted plants; on the other hand, it decreased to 26.93 in fruits from grafted plants.

The individual comparison of the grafted and ungrafted plants showed a different effect of the graft in the pulp color. Summer Flavor 840 showed higher luminosity value of mesocarp, showing a lighter flesh color (Figure 2A). Registered values were 48.3 in grafted condition, while the plants without graft showed 44.6. Color intensity (chroma) varied not when comparing plants with or without graft (Table 2). The pulp color purity of Summer Flavor 800 was higher, 2.7 in grafted plants, compared to ungrafted plants that registered a 27.5 value (Figure 2B). Color tone (hue) of the pulp by graft effect went to deeper red colors compared to plants without graft (Table 2). Sangria and Summer Flavor 840 were statistically different when compared individually to grafted and ungrafted conditions. The average value of the fruits of grafted plants was 26.3, while in plants without graft was 28.3 which represented less red color (Figure 2C). Similar results were found by Soteriou et al. (2017), who reported a less hue angle in grafted plants, evidenced by a deeper red color of the mesocarp than in plants without graft. However, the effect of the saline stress in the color of the watermelon mesocarp is unknown. So more studies are necessary to know if salinity influences the pulp color.

Firmness, ${ }^{\circ}$ Brix and lycopene of the pulp, had not significant increments in two of the three grafted cultivars (Table 2). Firmness increased in Sangria up to $3.5 \%$ and Summer Flavor 800 in 5.8\%. Both cultivars also presented higher concentration of solid soluble with an 
Table 2. Mean, standard error of the mean (SEM) and orthogonal contrast (C) of pulp quality parameters in three watermelon varieties under normal and grafted condition. Mexicali, UABC. 2012.

\begin{tabular}{|c|c|c|c|c|c|c|c|c|c|c|c|}
\hline \multirow{2}{*}{ Variables } & \multicolumn{3}{|c|}{ Normal plant } & \multicolumn{3}{|c|}{ Grafted plant } & \multirow{2}{*}{ SEM } & \multicolumn{4}{|c|}{${ }^{1}$ Contrast $P>F$} \\
\hline & Sangría & S.F 800 & S.F 840 & Sangría & S.F 800 & S.F 840 & & C1 & $\mathrm{C} 2$ & C3 & $\mathrm{C} 4$ \\
\hline Lightness $\left(\mathrm{L}^{*}\right)$ & 44.2 & 43.4 & 44.6 & 46.6 & 45.7 & 48.3 & 1.0 & 0.123 & 0.134 & 0.026 & 0.007 \\
\hline Chroma $\left(C^{*}\right)$ & 27.8 & 27.5 & 29.9 & 28.4 & 30.2 & 28.3 & 0.8 & 0.621 & 0.045 & 0.227 & 0.405 \\
\hline Hue angle $\left(\mathrm{h}^{\circ}\right)$ & 27.9 & 29.3 & 29.1 & 26.2 & 28.2 & 26.4 & 0.1 & 0.039 & 0.148 & 0.004 & 0.001 \\
\hline Firmness $(\mathrm{N})$ & 14.5 & 15.4 & 16.1 & 15.0 & 16.3 & 15.9 & 1.0 & 0.693 & 0.494 & 0.909 & 0.576 \\
\hline Brix degrees & 9.1 & 9.8 & 9.4 & 10.1 & 10.4 & 9.4 & 0.4 & 0.134 & 0.395 & 0.945 & 0.188 \\
\hline Lycopene $\left(\mathrm{mg} \mathrm{kg}^{-1}\right)$ & 42.6 & 41.1 & 43.4 & 42.6 & 43.4 & 40.9 & 4.8 & 0.995 & 0.748 & 0.722 & 0.987 \\
\hline
\end{tabular}

${ }^{1}$ Orthogonal contrast: $\mathrm{C} 1=$ Sangría vs Sangría grafted condition; $\mathrm{C} 2=$ Summer Flavor 800 vs Summer Flavor 800 grafted condition; C3= Summer Flavor 840 vs Summer Flavor 840 grafted condition; C4= normal plant vs grafted plant.

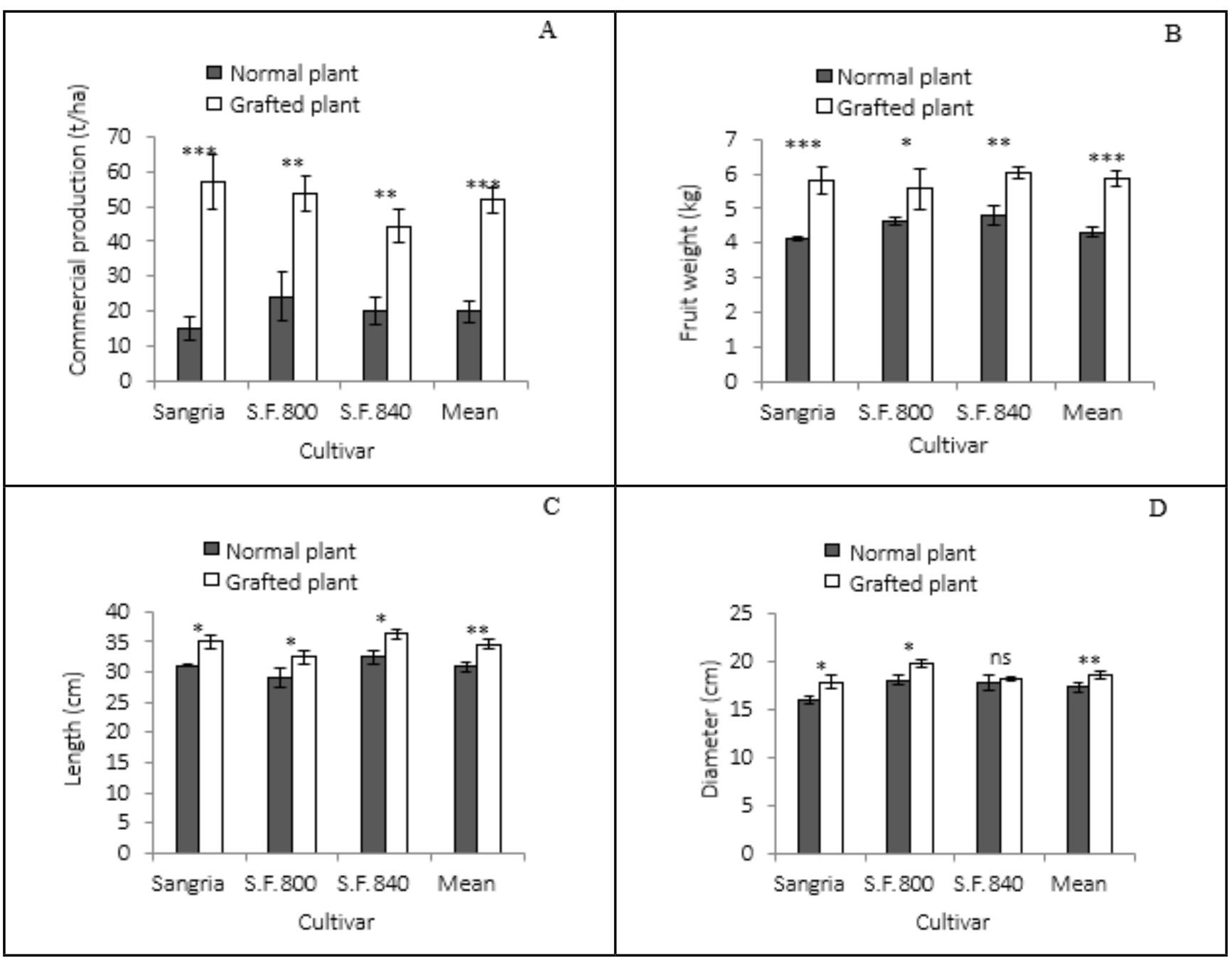

Figure 1. Commercial production (A), weight (B), length (C) and diameter (D) of fruit in three watermelon cultivars under normal and grafted condition. $n s=$ Non-significant; $*=p<0.05 ; * *=p<0.01 ; * * *=p<0.001$. Mexicali, UABC, 2012.

increment of 1.0 and 0.6 Brix grades in Sangria and Summer Flavor 800, respectively. Lycopene content of the pulp ranged between 41.1 and $43.3 \mathrm{mg}$ $\mathrm{kg}^{-1}$ of mesocarp between both plants. In other studies the increment of pulp firmness of grafted plants is attributed to the formation of a larger number and smaller size of parenchyma cells that increases resistance to puncture (Soteriou et al., 2017). This response of the cells was more notable in fruits developed without saline stress, where the mesocarp of the watermelon showed higher resistance to penetration in fruits from grafted plants in different maturity states (Soteriou et al., 2014). In contrast, Simpson et al. (2015) found that mini watermelon grafted with Strong Tosa showed a not significant increment of pulp firmness under $3 \mathrm{dS} \mathrm{m}^{-1}$ saline 


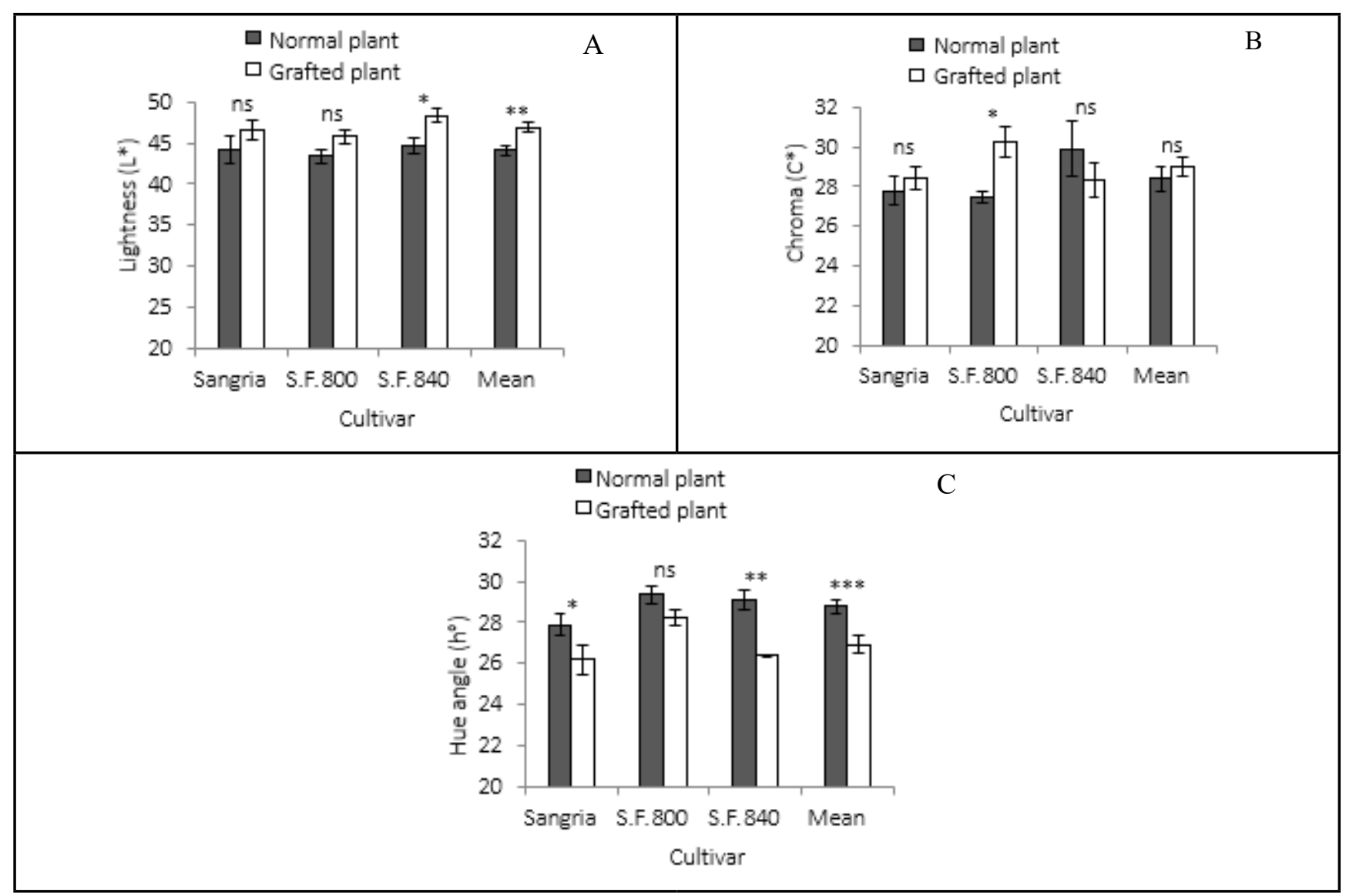

Figure 2. Lightness (A), chroma (B) and hue angle (C) of fresh fruit pulp in three watermelon cultivars under normal and grafted condition. ns= Non-significant; $*=\mathrm{p}<0.05 ; * *=\mathrm{p}<0.01 ; * * *=\mathrm{p}<0.001$. Mexicali, UABC, 2012.

concentration.

The ${ }^{\circ}$ Brix did not change by the graft. This is congruent with Colla et al. (2006), who reported similar values between grafted and not grafted plants of watermelon in $5.2 \mathrm{dS} \mathrm{m}^{-1}$ saline concentration. This is attributed to the capacity of restrict $\mathrm{Na}$ absorption and to get higher quantity of minerals like $\mathrm{Ca}$, $\mathrm{K}, \mathrm{P}, \mathrm{N}$ and $\mathrm{Mg}$ in saline environments (Yetisir \& Uygur, 2010; Uygur \& Yetisir, 2009; Huang et al., 2016).

Lycopene content of the pulp did no differ between the three cultivars, which allows us to deduct that the graft on Sangria, Summer Flavor 800 and Summer Flavor 840 with Strong Tosa as rootstock does not induce changes in the concentration of lycopene in the mesocarp of the fruit. In this sense, proteomic analysis shows that the phytoene saturase enzyme presents similar levels between grafted watermelon plants and without graft in saline condition (Yang et al., 2012). This enzyme is important in the synthesis of lycopene process of desaturations ( $\mathrm{Lv}$ et al., 2015).

In conclusion, the salinity of the soil is an adverse condition persistent in arid regions that affects the growth and development of the crops. Nevertheless, the implementation of the graft may be an alternative to reduce the negative effect caused by salinity in the plants. Graft in the three watermelon cultivars on the Strong Tosa pumpkin rootstock presented increments in performance, higher weight, longer fruit and larger diameter. Quality of the pulp was also slightly improved in parameters of coloration in chromaticity and hue. The cultivar that showed better answer was Sangria, followed by Summer Flavor 840 and Summer Flavor 800.

\section{REFERENCES}

ACOSTA, JA; FAZ, A; JANSEN, B; KALBITZ, K; MARTÍNEZ-MARTÍNEZ, S. 2011. Assessment of salinity status in intensively cultivated soils under semiarid climate, Murcia, SE Spain. Journal of Arid Environments 75:
1056-1066.

ALI, M; AYYUB, CM; SHAHEEN, MR; QADRI, RWK; KHAN, I; AZAM, M; AKHTAR, N. 2015. Characterization of watermelon (Citrullus lanatus) genotypes under high salinity regime. American Journal of Plant Sciences 6: 3260-3266.

COLLA, G; ROUPAHEL, Y; CARDARELLI, M; REA, E. 2006. Effect of salinity on yield, fruit quality, leaf gas exchange, and mineral composition of grafted watermelon plants. Hortscience 41: 622-627.

COLLA, G; ROUPHAEL, Y; JAWAD, R; KUMAR, P; REA, E; CARDARELLI, M. 2013. The effectiveness of grafting to improve $\mathrm{NaCl}$ and $\mathrm{CaCl}_{2}$ tolerance in cucumber. Scientia Horticulturae 164: 380-391.

COLLA, G; ROUPHAEL, Y; LEONARDI, C; ZHILONG, B. 2010. Role of grafting in vegetable crops grown under saline conditions. Scientia Horticulturae 127: 147-155.

D'SOUZA, MC; SINGHA, S; INGLE, M. 1992. Lycopene concentration of tomato fruit can be estimated from chromaticity values. Hortscience 27: 465-466.

DONG, Q; YANG, Y; ZHANG, T; ZHOU, L; HE, J; CHAU, H; ZOU, Y; HAO, F. 2018. Impacts of ridge with plastic mulch-furrow irrigation on soil salinity, spring maize yield and water use efficiency in an arid saline area. Agricultural Water Management 2001: 268-277. 
DUAN, JJ; LI, J; GUO, S; KANG, Y. 2008. Exogenous spermidine affects polyamine metabolism in salinity-stressed Cucumis sativus roots and enhances short-term salinity tolerance. Journal of Plant Physiology 165: 1620-1635.

EDELSTEIN, M; PLAUT, Z; BEN-HUR, M. 2011. Sodium and chloride exclusion and retention by non-grafted and grafted melon and Cucurbita plants. Journal of Experimental Botany 62: 177-184.

FURTANA, GB; TIPIRDAMAZ, R. 2010 Physiological and antioxidant response of three cultivars of cucumber (Cucumis sativus L.) to salinity. Turkish Journal of Biology 34: 287-296.

GORETA, S; BUCEVIC-POPOVIC, V; SELAK, GV; PAVELA-VRANCIC, M; PERICA, S. 2008. Vegetative growth, superoxide dismutase activity and ion concentration of salt-stressed watermelon as influenced by rootstock. Journal of Agricultural Science 146: 695-704.

HUANG, Y; ZHAO, L; KONG, Q; CHENG, F; NIU, M; XIE, J; NAWAZ, MA; BIE Z. 2016. Comprehensive mineral nutrition analysis of watermelon grafted onto two different rootstocks. Horticultural Plant Journal 2: 105-113.

LV, P; LI, N; LIU, H; GU, H; ZHAO, WE. 2015. Changes in carotenoid profiles and in the expression pattern of the genes in carotenoid metabolisms during fruit development and ripening in four watermelon cultivars. Food Chemistry 174: 52-59.

NIU, M; XIE, J; SUN, J; HUANG, Y; KONG, Q; NAWAZ, A; BIE, ZL. 2017. A shoot based $\mathrm{Na}^{+}$ tolerance mechanism observed in pumpkin -
An important consideration for screening salt tolerant rootstocks. Scientia Horticulturae 218: 38-47.

PULIDO-MADRIGAL, L. 2016. Cambio climático, ensalitramiento de suelos y producción agrícola en áreas de riego. Terra Latinoamericana 34: 207-218.

RIVERO, RM; RUÍZ, JM; ROMERO, L. 2003. Role of grafting in horticultural plants under stress conditions. Food, Agriculture \& Environment 1: 70-74.

ROUPHAEL, Y; CARDARELLI, M; COLLA, G; REA, E. 2008. Yield, mineral composition, water relations, and water use efficiency of grafted mini-watermelon plants under deficit irrigation. HortScience 43: 730-736.

SANJAY, P; JINAL, HN; AMARESAN, N. 2017. Isolation and characterization of drought resistance bacteria for plant growth promoting properties and their effect on chilli (Capsicum annuum) seedling under salt stress. Biocatalysis and Agricultural Biotechnology 12: 85-89.

Secretaria de Fomento Agropecuario. 2011. Estudio bibliográfico sobre la Salinidad del valle de Mexicali. Available at http://www. oeidrus-bc.gob.mx/oeidrus_bca/biblioteca/ Estudios/Agricolas/DOCUMENTO $\% 20$ SALINIDAD.pdf. Accessed on January 1, 2018.

SIMPSON, CR; KING, S; NELSON, SD; JIFON, J; SCHUSTER, G; VOLDER, A. 2015. Salinity evaluation for watermelon (Citrullus lanatus) grafted with different rootstocks. Subtropical Agriculture and Environments 66: 1-6.

SOTERIOU, GA; KYRIACOU, MC; SIOMOS, AS; GERASOPOULOS, D. 2014. Evolution of watermelon fruit physicochemical and phytochemical composition during ripening as affected by grafting. Food Chemistry 165: 282-289.

SOTERIOU, GA; SIOMOS, AS ; GERASOPOULOS, D; ROUPHAEL, Y; GEORGIADOU, S; KYRIACOU, MC. 2017. Biochemical and histological contributions to textural changes in watermelon fruit modulated by grafting. Food Chemistry 237: 133-140.

UYGUR, V; YETISIR, H. 2009. Effects of rootstocks on some growth parameters, phosphorous and nitrogen uptake watermelon under salt stress. Journal of Plant Nutrition 32: 629-643

YANG, Y; LU, X; YAN, B; LI, B; SUN, J; GUO, S; TEZUKA, T. 2013. Bottle gourd rootstockgrafting affects nitrogen metabolism in $\mathrm{NaCl}$ stressed watermelon leaves and enhances short-term salt tolerance. Journal of Plant Physiology 170: 653-661.

YANG, Y; WANG, L; TIAN, J; LI, J; SUN, J; HE, L; GUO, S; TEZUKA, T. 2012. Proteomic study participating the enhancement of growth and salt tolerance of bottle gourd rootstock-grafted watermelon seedlings. Plant Physiology and Biochemistry 58: 54-65.

YETISIR, H; UYGUR, V. 2010. Responses of grafted watermelon onto different gourd species to salinity stress. Journal of Plant Nutrition 33: 315-327.

ZONG, L; TEDESCHI, A; XUE, X; WANG, T; MENENTI, M; HUANG, C. 2011. Effect of different irrigation water salinities on some yield and quality components of two fieldgrown cucurbit species. Turkish Journal of Agriculture and Forestry 35: 297-307. 